BULLETIN Bulletin hispanique

HISPANIQUE Université Michel de Montaigne Bordeaux

116-1 | 2014

Varia

\title{
Envenenamiento y apariciones de don Carlos de
}

Viana

orígenes históricos y formación de una leyenda

Joan Mahiques Climent

\section{CpenEdition}

Journals

Edición electrónica

URL: http://journals.openedition.org/bulletinhispanique/3101

DOI: 10.4000/bulletinhispanique.3101

ISSN: $1775-3821$

Editor

Presses universitaires de Bordeaux

Edición impresa

Fecha de publicación: 1 junio 2014

Paginación: 13-38

ISBN: 978-2-86781-931-5

ISSN: 0007-4640

\section{Referencia electrónica}

Joan Mahiques Climent, «Envenenamiento y apariciones de don Carlos de Viana », Bulletin hispanique [En línea], 116-1 | 2014, Publicado el 01 junio 2017, consultado el 23 mayo 2020. URL : http:// journals.openedition.org/bulletinhispanique/3101; DOI : https://doi.org/10.4000/bulletinhispanique. 3101 


\title{
Envenenamiento y apariciones de don Carlos de Viana: orígenes históricos y formación de una leyenda ${ }^{1}$
}

\author{
Joan Mahiques Climent \\ Institut National d'Histoire de l'Art - París
}

À partir des témoignages qui vont du jour de sa mort le 23 Septembre 1461 jusqu'à la fin du XVII siècle sont analysées les rumeurs d'empoisonnement du prince Charles de Viane à l'instigation de sa marâtre et la relation de ce motif avec les apparitions de son âme criant vengeance.

Mots-clés: tradition orale, historiographie, empoisonnement, revenant.

A partir de testimonios que van desde su muerte el dia 23 de septiembre de 1461 hasta el final del siglo XVII, analizamos los rumores de envenenamiento del principe Carlos de Viana por instigación de su madrastra y la relación que este motivo tiene con el de las apariciones de su ánima reclamando venganza.

Palabras claves : tradición oral, historiografía, envenenamiento, ánima en pena.

In this paper we use several testimonies ranging from the day of his death, on September 23, 1461, to the end of the $17^{\text {th }}$ century, to examine the rumours of Prince Carlos de Viana's death by poisoning at his stepmother's instigation, and its relation with the motif of his soul appearing to cry out for revenge.

Keywords: oral tradition, historiography, poisoning, ghost.

1. Este artículo aprovecha parte de los materiales que el autor reunió durante su estancia postdoctoral en el Institut National d'Histoire de l'Art, en relación a un proyecto que tiene como tema central el estudio de relatos sobre apariciones de difuntos, poniendo especial énfasis en la cultura catalana de los siglos XIV-XVII. Este proyecto ha sido financiado a través del programa Beatriu de Pinós (BP-DGR 2009) en su modalidad A; cuenta con la tutela de la Dra. Marie Anne Polo de Beaulieu y se integra en el GAHOM (Groupe d'Anthropologie Historique de l'Occident Médiéval). 


\section{INTRODUCCIÓN}

El primer príncipe de Viana -don Carlos de Evreux (1421-1461)-, heredero de Navarra y primogénito de Aragón, ocupa un lugar preeminente en el contexto hispánico del final de la Edad Media. Un breve repaso por su biografía nos haría ver algunos de los rasgos, cualidades y virtudes que muchos testimonios y autores, antes y después de su fallecimiento y a lo largo de muchos siglos, destacaron de su personalidad, cuya relevancia transciende la historia y se inserta en el ámbito de lo legendario ${ }^{2}$. El tópico retrato de don Carlos pone énfasis en su amor a la sabiduría y a las letras, en sus continuos fracasos políticos, en su carácter afable y melancólico y en su natural enfermizo; pero este trasunto, que podría corresponderse más o menos con el personaje real, se vio enriquecido póstumamente por una serie de rumores que no solo le dieron fama de santo y de taumaturgo sino también de víctima de homicidio. El hilo argumental de esta leyenda, con su trasfondo ideológico, constituye una defensa del hombre humilde, virtuoso y justo que el tirano orgulloso pisotea usurpando sus derechos y detentando el poder. Por eso, no debe extrañarnos que, en épocas y lugares distintos, el relato de don Carlos haya inspirado un difuso sentimiento de simpatía y compasión. Esto es así hasta tal punto que nos atreveríamos a decir que, desde una perspectiva cultural, no menos importante que su vida fue el mito que comenzó a gestarse justo después de su muerte, acaecida en Barcelona el 23 de septiembre de 1461.

Sabemos que a los pocos días de esta fecha, y también durante el inicio de la guerra civil de Cataluña (1462-1472), la voz del vulgo y la propaganda política daban por seguro que el príncipe era un santo, que obraba milagrosas

2. La figura de don Carlos, príncipe de Viana, ha centrado el interés de muchas obras de carácter histórico-biográfico, de las cuales solo mencionaremos una pequeña parte: Georges Desdevises du Dézert, Don Carlos de Aragón, principe de Viana. Estudio sobre la España del norte en el siglo XV. Edición y traducción: Pascual Tamburri Bariain, Pamplona, Gobierno de Navarra, 1999; Manuel Cruells, El príncep Carles de Viana, Barcelona, Barcino, 1935; Manuel Iribarren, El principe de Viana (un destino frustrado), Barcelona, Montaner y Simón, 1947; Jaume Vicens i Vives, "Trayectoria mediterránea del príncipe de Viana (1458-1461)», en Obra dispersa. A cura de M. Batllori i E. Giralt. Catalunya ahir i avui. Pròleg de Ramon d'Abadal i de Vinyals, Barcelona, Editorial Vicens-Vives, 1967, p. 83-108; Antoni Closas, El primogènit Carles, Princep de Viana, Barcelona, Rafael Dalmau, 1977; Eloísa Ramírez Vaquero y Pascual Tamburri Bariain, El príncipe de Viana, Pamplona, Gobierno de Navarra, 2001. A estas obras ańadiremos otras que serán citadas a lo largo de este artículo. Sobre la fama de santidad y los milagros del príncipe, vid. J. M. a Font i Rius, «La tradició de la santedat del príncep de Viana», La Paraula Cristiana, no 117, 1934, p. 196-223; J. M. ${ }^{a}$ Font i Rius, «El príncep de Viana a la Seu de Barcelona. Algunes notes sobre la veneració popular de Carles de Viana», Analecta Sacra Tarraconensia. Anuari de la Biblioteca Balmes [Homenatge a Antoni Rubió i Lluch], no 12, 1936, p. 541-557; Eduard Toda, «La tragèdia final del príncep de Viana», en Discursos llegits en la Real Academia de Buenas Letras de Barcelona en la solemne recepció pública del iltre. Sr. D. Eduard Toda el dia 2 de desembre de 1930, Barcelona, Imp. «La Renaixensa», 1930, p. 1-27 (especialmente las p. 1317); y José Luis Martín Rodríguez, «Biografía y leyenda del Príncipe de Viana -sant Carles de Viana-», en Tópicos y realidades de la Edad Media (III). Eloy Benito Ruano (Coord.), Madrid, Real Academia de la Historia, 2004, p. 27-67. 
curaciones, que protegía a los soldados catalanes amotinados contra su padre el rey Juan II (1398-1479) y que había sido envenenado por su madrastra Juana Enríquez (1425-1468). Todos estos ingredientes los hallamos en fuentes datadas desde el óbito de don Carlos hasta el final de la guerra civil. Es verdad que solo a partir de la crónica de Lucio Marineo De rebus Hispaniae memorabilibus (Alcalá de Henares, 1533) comenzamos a encontrar alusiones explícitas a las apariciones del príncipe por las calles de Barcelona, reclamando venganza contra los responsables del envenenamiento. Esta imagen responde al paradigma de los espectros de víctimas de asesinatos $\mathrm{u}$ otras muertes violentas o sospechosas que divulgan el secreto y reclaman o ejecutan la venganza. Precisamente por eso el envenenamiento y las apariciones del príncipe de Viana son dos elementos indisociables. Uno de los propósitos de nuestro trabajo es analizar estos dos aspectos tanto en los documentos coetáneos como en la historiografía posterior de tal manera que podamos distinguir cómo y hasta qué punto este núcleo narrativo se fue gestando en los días, meses y años que siguieron al 23 de septiembre de 1461. La confrontación de textos de diversas épocas también nos permitirá establecer distintos estadios en la formación y evolución de esta leyenda.

Podríamos decir que, gracias a las aportaciones de diversas obras historiográficas, los motivos argumentales que sustentan el relato del envenenamiento y las apariciones van creciendo levemente desde el siglo XVI hasta el inicio de la siguiente centuria. La incorporación de nuevos ingredientes podría responder a un proceso de literaturización en el que diferentes autores irían añadiendo matices, quizás de cosecha propia, ausentes en la tradición escrita u oral precedente. De todos modos, algunos de los testimonios más destacados y extensos apelan a la cultura urbana de transmisión oral, como sucede de manera muy significativa en los Col.loquis de la insigne ciutat de Tortosa de Cristòfor Despuig, cuya vida se enmarca entre los años $1510 \mathrm{y}$ $1574^{3}$. Esto nos hace suponer que, en realidad, esta leyenda no es el mero producto de una trama intertextual entre diversas fuentes historiográficas -aunque dicha trama sea incuestionable-. Al fin y al cabo, ya desde la muerte de don Carlos, se consolidó la fama de su santidad y sus milagros como consecuencia no solamente de una serie de rumores y devociones populares que se insertan en la tradición viva y en la oralidad, sino también a través de la correspondencia escrita y de los embajadores enviados por la Diputación y el Consejo del Principado de Cataluña.

Casi todos los textos historiográficos que hablan del envenenamiento fueron escritos después de la muerte de Juan II y, por tanto, rememoran los hechos desde una cierta perspectiva y de manera bastante concisa, pues tienen la ventaja de relatar con toda claridad el devenir de los acontecimientos. En cambio, los documentos inmediatamente posteriores al óbito de don Carlos insinúan este mismo tema de manera críptica, velada y sumamente cauta;

3. Cristòfor Despuig nació en 1510, y redactó su testamento en agosto de 1574, según indica Enric Querol Coll, «Cristòfol Despuig, pugna pro patria. Noves dades biogràfiques sobre l'autor dels Col.loquis», Llengua \& Literatura, no 16, 2005, p. 247-288. 
parecen más bien el reflejo escrito y decoroso de habladurías que se estaban extendiendo rápidamente por el entorno de la ciudad de Barcelona. La poca claridad con la que estos papeles - conservados en el Archivo de la Corona de Aragón- aluden al supuesto envenenamiento contrasta con la profusión de detalles que estos mismos dan sobre la santidad y los milagros del príncipe. Las pocas e imprecisas referencias a una muerte provocada son presentadas como nefandísimas opiniones de la muchedumbre barcelonesa que afectan a la honorabilidad de la reina, pero en ningún momento se nos dice de qué se trataba exactamente y si estas murmuraciones eran simples calumnias o tenían algún fundamento real. Una simple cuestión de corrección diplomática podría justificar que estas notas se expresasen con una indeterminación bien calculada que se limita a mencionar algo gravísimo sin decir qué -para nosotros, un presunto envenenamiento maquinado por Juana Enríquez.

Con el propósito de facilitar la comprensión de los diferentes aspectos que trataremos en este artículo, hemos optado por presentar en primer lugar el análisis de las fuentes historiográficas posteriores al año 1472, menos enigmáticas, más explícitas y hasta cierto punto más completas. De esta manera, el lector podrá hacerse una idea general de los elementos que constituyen la leyenda del príncipe de Viana; y a nosotros, después, nos resultará más sencillo exponer nuestro análisis del significado y el contexto de los testimonios escritos hasta el año 1472, que destacan no solamente por su fragmentarismo sino también por la cercanía y repercusión inmediata que, tanto a nivel político como social, otorgan a los hechos.

\section{Fuentes historiográficAs DESDE EL AÑO I 472 HASTA EL FINAL DEL SIGLO XVII}

Si nos centramos en las fuentes posteriores a la guerra civil de Cataluña, la primera noticia historiográfica que da fe de un presunto envenenamiento de don Carlos la hemos localizado en el libro VI de la primera década de la Gesta Hispaniensia de Alfonso de Palencia (1424-1492): "Prima fuit insimulatio ueneficii, quo principem Carolum seuitate nouercae extinctum esse affirmabant, uelut immemores diuturnae ualetudinis et paraliticae egritudinis ${ }^{4}$. Esta obra también es conocida con el título de Décadas o Crónica de Enrique $I V$, que según la crítica se escribió en diferentes períodos, poco antes y poco después del año $1477^{5}$. Se inspiran en Alfonso de Palencia tres crónicas intertextualmente

4. «La primera acusación era que Carlos había muerto envenenado por su cruel madrastra, como si se olvidaran de su larga enfermedad y achaques paralíticos», Alfonso de Palencia, Gesta Hispaniensia ex annalibvs svorvm diervm collecta. Tomo 2. Libri VI-X. Edición, estudio y notas de Brian Tate y Jeremy Lawrance, Madrid, Real Academia de la Historia, 1999, p. 231. De esta edición citamos tanto el texto latino como la traducción al castellano. La primera década («Decas prima») abarca la historia hispánica de los años 1440-1468.

5. La crónica fue escrita poco después de 1477 según la opinión de A. Paz y Meliá, El cronista Alonso de Palencia: su vida y sus obras; sus "Décadas» y las "Crónicas» contemporáneas; ilustraciones de las "Décadas» y notas varias, Madrid, Hispanic Society of America (Tipografía de la Revista de 
relacionadas y escritas en fechas próximas. En primer lugar, la anónima Crónica de Enrique IV de Castilla ha sido datada entre los años 1481-1482; en segundo lugar, el Memorial de diversas fazañas de Diego de Valera (1412-1488) se considera redactada durante los años 1486-1487; finalmente, la Crónica de Enrique IV de Lorenzo Galíndez de Carvajal (1472-1525) es posterior a las otras dos. Las tres crónicas refieren con las mismas palabras cómo los barceloneses «començaron a dezir e afirmar el prinçipe don Carlos ser muerto con yervas por su madrasta $»^{6}$. Estas compilaciones nada dicen sobre las apariciones del príncipe de Viana, que por primera vez son aludidas por Lucio Marineo (1460-1533) en la crónica titulada De rebus Hispaniae memorabilibus (Alcalá de Henares, 1533) y en su traducción castellana De las cosas memorables de España (Alcalá de Henares, 1539). Citaremos a continuación ambas versiones:

Ideoque prius quam Rex aduenisset, tumultus ingentes inter eos nouaeque seditiones ortae fuere. Simularunt enim tantum metus improbos coegit, animam Caroli Principis defuncti de patre deque nouerca noctu per vicos ciuitatis miserabiliter quaesta $m$, multaque miracula fecisse. Perinde ac si non morbo naturalique morte Carolus sed aliqua re interceptus \& sublatus fuisset. Sic itaque cum se animaduersione dignos agnoscerent, \& poenae metu quiescere non possent, huius fictionis velamento
Y por tanto, antes que el rey viniese començaron a fingir entre ellos nuevos espantos y temores, porque inventaron entre sí, fingidamente, que el ánima del príncipe don Carlos ya defunto se quexava de noche, por las calles, de su padre y de su madrastra con gemidos y bozes tristes que era lástima de oyr, haziendo cosas de espanto y grande admiración como si no muriera de enfermedad y muerte natural y como fiel y cathólico, mas si como por alguna industria le fuera antes de tiempo cortado el hilo de vida. Así que como ellos se hallassen dignos de castigo y con temor de la pena que merecían y no pudiessen

Archivos), 1914, p. xxxix. Esta datación es matizada por Fernando Gómez Redondo: «En 1477, Palencia se consideraba secretario del rey e instaba, cerca de Sevilla, a Isabel a que esperara a su marido para ser recibida en la ciudad. Importa este último año porque, para entonces, Palencia tenía que haber formado ya las tres primeras décadas de Gesta Hispaniensia [...] En 1480, en las cortes de Toledo, será sustituido por Pulgar en el cargo de cronista real, tras el enfrentamiento directo con la reina; Palencia presentaba a Isabel la cuarta década», Fernando Gómez Redondo, Historia de la prosa medieval castellana. IV [El reinado de Enrique IV: el final de la Edad Media. Conclusiones. Guía de lectura. Apéndices. Indices], Madrid, Cátedra, 2007, p. 3512.

6. María Pilar Sánchez-Parra, Crónica anónima de Enrique IV de Castilla, 1454-1474. (Crónica castellana). Edición crítica y comentada de María Pilar Sánchez-Parra, Madrid, Ediciones de la Torre, 1991, 2 vol., 2, p. 115. Cf. Diego de Valera, Memorial de diversas hazañas. Crónica de Enrique IV, ordenada por mosén Diego de Valera. Edición y estudio de Juan de Mata Carriazo, Madrid, Espasa-Calpe, 1941, p. 66; y Juan Torres Fontes, Estudio sobre la "Crónica de Enrique IV" del Dr. Galíndez de Carvajal, Murcia, Consejo Superior de Investigaciones Científicas / Instituto Jerónimo de Zurita / Seminario de Historia de la Universidad de Murcia, 1946, p. 195. Sobre la cronología y las relaciones existentes entre estas crónicas castellanas y las Décadas de Alfonso de Palencia, vid. Fernando Gómez Redondo, op. cit., p. 3517-3522; María Pilar Sánchez-Parra, op. cit., 1, p. clxxv-clxxvii; que revisa y actualiza las aportaciones de Diego de Valera, op. cit., p. lxvii-xcii; y A. Paz y Meliá, op cit., p. xxxvii-xliv. 
rursus omnes in regem conspirant et, quae finxerant, Caroli diuulgatis miraculis, totius prouinciae populos in fanaticos impulere furores ${ }^{7}$. reposar, so color y especie de aquella ficción, tornaron otra vez a juntarse unos con otros y hazer liga contra el rey y publicar ya las cosas que avían inventado sobre el ánima de don Carlos viendo como los pueblos casi de toda la provincia querían consentir en aquellas desatinadas y fingidas fantasías ${ }^{8}$.

La comparación entre los textos latino y castellano nos permite observar algunas diferencias evidentes. En primer lugar, salta a la vista la extensión mucho mayor de la traducción, que en realidad amplifica y exagera los hechos. El adverbio "miserabiliten", referido al espectro de don Carlos, equivale en castellano a la oración subordinada «con gemidos y bozes tristes que era lástima de oyr». Los milagros de los que habla el original («multaque miracula») se entienden como cosas admirables y espantosas en la versión castellana, donde además se omite la siguiente oración subordinada temporal: "Caroli diunlgatis miraculis.» Este fragmento forma parte de un pasaje que vincula los milagros de don Carlos con la revuelta popular contra Juan II. Podríamos decir que, a partir de la traducción castellana de la crónica De rebus Hispaniae memorabilibus, tienden a separarse las dos tramas fundamentales de la fama póstuma de don Carlos: por una parte, su santidad y sus milagros; por otra parte, su envenenamiento y sus apariciones?

Con el tiempo, esta última trama argumental viene marcada por un progresivo desarrollo del papel de la antagonista, la madrastra. Así sucede en una obra que no muestra ningún interés particular por la fama de santidad y milagros del príncipe: nos referimos a los Col-loquis de la insigne ciutat de Tortosa de Cristòfor Despuig, cuya dedicatoria al conde de Aitona data del año 1557. Entre los diferentes diálogos que forman los Col-loquis, el quinto retoma el pasaje de Lucio Marineo y otros argumentos que esgrime este cronista contra la nación catalana. Según reza el título del quinto diálogo, en él «se tracta de la guerra que lo Principat de Catalunya tingué amb lo rei don Joan, segon d'aquest

7. Lucio Marineo Sículo, L. Marinei Sicvli regii historiographi opus de rebus Hispaniae memorabilibus modo castigatum atq. Caesareae maiestatis iussu in lucem aeditum, impressum Compluti per Michaelem de Eguia, 1533, f. $\operatorname{xxvj}^{\mathrm{r}-\mathrm{v}}$. Hemos transcrito el texto alterando levemente la puntuación y marcando las abreviaturas en cursiva.

8. Josep Solervicens, Els Països Catalans i Espanya: ser o no ser. Conflictes politico-lingüistics al segle XVI, Valencia, Tres i Quatre, 1988, p. 161-162. Este mismo pasaje también aparece en una edición parcial y resumida, que se publicó en la imprenta valenciana de Juan Navarro en el año 1541: la Crónica del rey don Juan de Aragón, segundo d'este nombre, abreviada, que ha sido estudiada y modernamente editada por Nieves Baranda, "Una crónica desconocida de Juan II de Aragón (Valencia, 1541)», Dicenda. Cuadernos de Filología Hispánica, no 7, 1987, p. 267-288 (vid. especialmente la p. 280).

9. A continuación nos centraremos en los textos referidos al envenenamiento o a las apariciones de don Carlos, pero ya desde el siglo XV hay otras obras que solamente aluden a su santidad y sus milagros, como sucede en la Vita Iohannis II Aragonum regis de Gonzalo García de Santamaría o en los Anales de Aragón de Jerónimo Zurita. Estos y otros casos son aducidos por José-Luis Martín Rodríguez, op. cit., p. 40-48. 
nom, per la capció $i$ mort del princep don Carlos; $i$ mostra's lo descàrrec de la nació catalana $i$ l'ocasió que tingué per a fer aquella guerra» ${ }^{10}$. A través de Lucio -uno de los personajes que intervienen en los coloquios-, Despuig se suma a la polémica sobre el envenamiento y las apariciones inspirándose en el citado fragmento de la traducción De las cosas memorables de España:

Lo que es troba en escriptura i procés és que l'ànima del princep, pocs dies aprés que fonc fora del cos anà moltes nits per Barcelona cridant a veu plena i publicant que la reina la madrastra l'havia fet morir amb metzines, i d'açò feia grans queixes, com que demanava venjança ${ }^{11}$.

Ahora bien, a diferencia de Marineo o de los cronistas de la época de Fernando el Católico, Despuig tiene la ventaja de ser un autor vinculado a Cataluña, el lugar en donde surgieron y más arraigaron tales rumores. Precisamente por eso el autor catalán añade un considerable número de detalles que, además de aportar nuevos datos, tienen el interés de apelar a una tradición oral cuya continuidad podría constatarse en el siglo XVI como mínimo durante las primeras décadas de la vida de Despuig. Los Col.loquis advierten que el príncipe murió tres días después de que se le administrase la ponzoña, y que las murmuraciones daban diferentes versiones del homicidio, aunque una de las que se tenían por más ciertas aseguraba que el veneno fue mezclado con agua de mirto o arrayán, tal como insinúa "un principi d'unes cobles que per aquell acte se cantaren leshores $i$ molts anys aprés per tota la terra, que diu: "plegue a Dios que a bien surta el lavar del agua murta" ${ }^{12}$. De gran utilidad para nuestro tema de estudio hubiese sido la conservación de estas coplas que, si exceptuamos sus dos primeros versos, podemos dar por perdidas. El agua de arrayán es una sustancia medicinal popularmente conocida y, en este aspecto, el pasaje de los Col.loquis podría relacionarse claramente con los testimonios que acusaban del homicidio a un médico o a un especiero, tal como veremos más adelante ${ }^{13}$.

10. Cristòfor Despuig, Los col-loquis de la insigne ciutat de Tortosa. Edició critica d'Enric Querol i Josep Solervicens, Barcelona, Publicacions de l'Abadia de Montserrat, 2011, p. 131. Sobre la relación de los Col.loquis con la crónica de Lucio Marineo, vid. Josep Solervicens, El diàleg renaixentista: Joan Lluís Vives, Cristòfor Despuig, Lluis Milà, Antoni Agustí, Barcelona, Publicacions de l'Abadia de Montserrat, 1997, p. 161-162; Eulàlia Duran, «La funció de les llegendes en la historiografia», Estudi General, no 23-24, 2003-2004, p. 63-79 (especialmente las p. 75-76); Joan Mahiques, «Les ànimes d'ultratomba: una justificació propagandística», Estudi General, no 23-24, 2003-2004, p. 143-160 (especialmente las p. 153-154).

11. Cristòfor Despuig, op. cit., p. 141.

12. Ibid., p. 141.

13. La traducción catalana medieval del tratado de Ibn Wafid sobre medicinas nos advierte: «Dix .Gal. que la murta es composita de compliçio freda e sequa e es aspre en la ssabor e la ffulla e l gra fe tot .j. ${ }^{\text {a }}$ obra en estrenyer e en confortar. Dix .D. que la murta, ço es la fulla e el gra que estrenyen, e quan es donat a menjar val a l escopir de la ssang, e a la cuytor de la vexiga e conforta 1 estomag e soluu la orina e val a la mordedura de les cuques verinoses [...] E 1 exirop de la murta va a la tos e talle la menao que es de calor e vede la flor e val a l escopir de la ssang per ço cor el estreyn, e per ço cor el es aspre e dolç val a la menao de la tos», Luis Faraudo de Saint-Germain (ed.), El «Libre de les medicines particulars». Versión catalana trescentista del texto árabe del tratado de los medicamentos simples de Ibn Wáfid, autor médico toledano del siglo XI. Transcripción, estudio 
Buena parte del interés del relato de Cristòfor Despuig radica en la importancia que la madrastra va adquiriendo en la trama argumental, y no solamente como maquinadora del homicidio con el consentimiento tácito del rey, pues a este elemento se añaden otros que son de suma importancia en la evolución de la leyenda. Los Col-loquis nos advierten que, con el mal propósito de hacer que su hijo Fernando reinara después de su marido, la reina cometió el horrendo crimen, ya que su hijo no podía ser el primogénito mientras don Carlos viviese. También refieren la célebre lamentación que ella pronuncia antes de morir, ante Fernando: «Ay, hijo mío, tú te quedas y sabes que para reinar, pero yo triste me voy y no sé si para penar $\aleph^{14}$. Asimismo, los Col-loquis confirman la difusión oral de otra noticia que daba por cierto que Juana Enríquez se había condenado al infierno. Poco después de su muerte, unas beatas que habían tenido una revelación particular sobre el caso aseguraron a las monjas del monasterio de Jerusalén, en Barcelona, que la reina no estaba en vía de salvación. Este aviso fue corriendo a través de las diferentes generaciones de monjas del monasterio, hasta llegar a la época en que se ambientan los Col.loquis, que ponen de relieve las buenas relaciones que la reina había tenido con dichas religiosas, otorgando de este modo mayor credibilidad a esta fuente oral ${ }^{15}$.

Otro importante núcleo catalán de la difusión de la leyenda de don Carlos queda focalizado en el monasterio de Poblet, a donde su venerado cuerpo fue trasladado en el año 1491. Al fray Joan Vallespinosa (c. 1578-1640) debemos una Historia del principe don Carlos, hijo del rey don Joan, todavía inédita, que se centra en la santidad y los milagros del príncipe eludiendo el tema del envenenamiento y las apariciones ${ }^{16}$. Sea como sea, si nos centramos en la figura de la madrastra, la historiografía hispánica oponía ya desde el siglo XV dos versiones diferentes de su muerte, tal como indica Nuria Coll Juliá:

En una de ellas, recogida por los autores catalanes y navarros, la reina, inquieta, revela en su lecho de muerte al rey el secreto terrible de haber sido la envenenadora del príncipe de Viana, desde cuyo fallecimiento un horrible cáncer corroía su garganta. Don Juan, horrorizado, se apartó de su esposa.

proemial y glosarios por Luis Faraudo de Saint-Germain, Barcelona, Real Academia de Buenas Letras de Barcelona, 1943, p. 73-74. Sobre las aplicaciones medicinales del mirto o arrayán, vid. también César E. Dubler, La "Materia Médica» de Dioscórides. Transmisión medieval y renacentista. Vol. III: La "Materia Médica" de Dioscórides traducida y comentada por D. Andrés de Laguna (texto crítico), Barcelona, Tipografía Emporium, 1955, p. 37, 99-100, 463-464 y 518.

14. Cristòfor Despuig, op. cit., p. 144.

15. Vid. Cristòfor Despuig, op. cit., p. 144; Eulàlia Duran, op. cit., p. 76; Joan Mahiques, op. cit., p. 154-155.

16. El único testimonio conocido de esta obra forma parte del ms. 14 de la Biblioteca del Seminario Diocesano de Girona, que cuenta con una detallada descripción de Eulàlia Duran (dir.), Repertori de manuscrits catalans (1474-1620). Volum IV. Direcció: Eulàlia Duran. Compilació a cura de: Maria Toldrà (coordinació), Mar Batlle, Carme Camps, Antoni Cobos, Joan Mahiques, Eulàlia Miralles, Enric Querol, Joan Requesens, Glòria Sabaté, Barcelona, Institut d'Estudis Catalans, 2008, p. 81-93. A esta biografía de don Carlos también se refiere Eulàlia Duran, op. cit., p. 77. 
Absolutamente distinta es otra versión, en la que ya la enfermedad, en vez de castigo de un crimen espantoso, es originada por un exceso de amor conyugal hacia los sufrimientos que la ceguera habría producido a don Juan II; en vez de revelar horrendos misterios a su esposo, le exhorta con cristianas confortaciones y expira en un completo despego de las cosas temporales. Así vieron su muerte los analistas castellanos ${ }^{17}$.

Claro está que para el estudio de la leyenda de don Carlos de Viana es más importante la primera de las dos versiones, que prevaleció a lo largo de los siglos XVI-XVII. Si un coetáneo de Cristòfor Despuig como es Esteban de Garibay (1533-1600) se limita a mencionar que el príncipe murió «con sospecha de veneno» ${ }^{18}$, fray Gregorio de Argaiz en La perla de Cataluña (Madrid, 1677) otorga un protagonismo mayor a la madrastra:

Murió el príncipe de Viana don Carlos, que es lo que doña Juana Enríquez -su madrastra- deseava, y no sin sospecha de veneno. Murió doña Blanca, con más que sospechas de lo mesmo, y manuescrito he leído en que lo confessó la reyna, al tiempo del morir, al rey don Joan -su marido-, que avía dado veneno al príncipe don Carlos $^{19}$.

En la segunda parte de los Anales históricos de los reyes de Aragón, Pedro Abarca (1619-1693) se refiere al «veneno que unos creyeron se le avía dado ya en la prisión de Mirabet y otros que dentro de Barcelona, y todo por la diligencia de la madrastra, aunque tan virtuosa ${ }^{20}$. También advierte cómo se divulgaron los rumores de los milagros y apariciones del príncipe:

unos publicaron y otros creyeron grandes y muchos milagros que Dios obraba para manifestar la santidad del principe d[on] Carlos, que empezó a ser venerado por santo, por aquella boba devoción con que el vulgo fácil y necio suele creer semejantes fantasmas y notar de impíos a los hombres que con juizio

17. Nuria Coll Juliá, Doña Juana Enríquez, lugarteniente real en Cataluña (1461-1468), Madrid, Consejo Superior de Investigaciones Científicas,1953, 2 vol., 2, p. 236-237. Vid. también las p. 3-18 del vol. 1 de esta misma obra, y Georges Desdevises du Dézert, op. cit., p. 409; Manuel Iribarren, op. cit., p. 242-243; y Laura Vivanco, Death in fifteenth-century Castile: ideologies of the elites, Woodbridge, Tamesis, 2004, p. 53-54.

18. Esteban de Garibay y Çamalloa, Compendio historial de las chronicas y vniversal historia de todos los reynos d'España, donde se ponen en summa los condes, señores de Aragon, con los Reyes d'el mesmo reyno: y condes de Barcelona, y reyes de Napoles y Sicilia, Anveres, Christophoro Plantino, 1571, p. 1176. Los ejemplares de esta edición de 1571 se suelen conservar en 4 volúmenes, de los cuales los dos primeros tienen una numeración correlativa y los dos últimos otra. El fragmento que hemos citado pertenece al segundo volumen, donde no figura ni el título de la obra ni la fecha ni el lugar ni el impresor. Referenciamos estos datos según aparecen en el volumen primero y el cuarto. A partir de ahora, al citar fuentes del siglo XVII en castellano, transcribiremos el texto resolviendo las abreviaturas en cursiva, alterando levemente la puntuación, y regularizando la acentuación, el uso de mayúsculas y la alternancia $u / v$ y $i / j$ según la normativa actual.

19. Gregorio de Argaiz, La perla de Cataluña. Historia de Nvestra Señora de Monserrate, Madrid, Imprenta de Andrés García de la Iglesia, 1677, p. 104.

20. Pedro Abarca, Segunda parte de los anales historicos de los reyes de Aragon por el p. maestro Pedro Abarca, Salamanca, Lucas Pérez, 1684, f. 257 
hacen justa burla de essa vana credulidad, la qual se hizo más furiosa con la ciega fama y persuasión de que la alma del príncipe aparecía y vagueaba de noche por las calles de Barcelona, quexándose de la muerte que su madrastra le avía dado ${ }^{21}$.

La historiografía francesa, celosa por reivindicar los derechos de su monarquía sobre los reinos hispánicos en general y sobre Navarra en particular, también se centra más en la leyenda del envenenamiento del príncipe de Viana que en la fama de sus milagros ${ }^{22}$. Así sucede en una obra impresa en Amberes en 1582 y escrita por Pierre de Belloy, juez de Tolosa; o, poco después, en una historia del reino de Navarra donde su autor, Gabriel Chappuys, cuenta cómo murió el príncipe don Carlos «non sans grande opinion d'avoir esté empoisonné [...] par les practiques de D [ona] Jeanne, sa maratre» ${ }^{23}$. Este analista también alude al castigo de Juana Enríquez por haber cometido semejante crimen:

La commune \& constante renommée est que, despuis que le prince sortit de celle prison, il n'eut un seul jour de santé \& alla sa vie en décadence \& consomption évidente de jour en jour, tant qu'en bref il fut estaint; \& donnent ce blasme plusieurs à la royne Don[a] Jeanne de l'avoir empoisonné à fin d'avancer au droit de primogéniture \& succession au royaume d'Arragon \& dépendances d'iceluy son fils D[om] Ferdinand, lors duc de Momblanc, estant ministre de telle méchanceté un certain médecin estranger. Tost après fut saisie la royne d'un cancer, Dieu la punissant d'un si exécrable forfait. Autres rejettent ceste accusation comme fausse ${ }^{24}$.

Al pastor protestante Pierre Olhagaray debemos una historia conjunta del condado de Foix, del vizcondado de Bearn y del reino de Navarra. Esta obra, impresa en París en 1609, no solamente nos explica los rumores sobre el envenenamiento y las quejas del espectro de don Carlos sino que también añade un portento notable provocado por el sol que vendría a confirmar la culpabilidad de la madrasta. De todos modos, este portento parte de una confusión al atribuir a Juana Enríquez un suceso que en realidad pertenece a la biografía de Juana de Castilla:

21. Pedro Abarca, op. cit., f. $257^{\text {ra }}$.

22. Las alusiones que Olhagaray, Favyn y otros autores franceses del siglo XVII hacen al supuesto crimen de Juana Enríquez son estudiadas por Nuria Coll Juliá, op. cit., 1, p. 15-18.

23. [Gabriel Chappuys], L'histoire dv Royavme de Navarre, contenant de Roy en Roy tout ce qui y est aduenu de remarquable des son origine, París, Nicolas Gilles, 1596, p. 485. El autor de esta obra se presenta él mismo como "Secretaire interprete de vostre Majesté», y debe identificarse con Gabriel Chappuys. A partir de ahora, al citar fuentes francesas de los siglos XVI-XVII, transcribiremos el texto resolviendo las abreviaturas en cursiva, alterando levemente la puntuación, y regularizando la acentuación, el uso de mayúsculas y la alternancia $u / v$ y $i / j$ según la normativa actual y los usos más frecuentes entre editores de textos antiguos en francés. Aparte del pasaje de Gabriel Chappuys, vid. [Pierre de Belloy], Declaration dv droit de legitime svccession sur le royavme de Portugal, apartenant à la Royne mere du Roy Treschrestien [...] Par M. P. BE. IV. TH., Anvers, s/n, 1582, f. 86 ("ladite Jeanne luy eut fait donner du poison, duquel il mourut tost après, au grand regret des Cathalans»). Las iniciales que figuran en la portada de este impreso se refieren a Monsieur Pierre de Belloy, juez de Tolosa.

24. [Gabriel Chappuys], op. cit., p. 482. 
Ce brave prince Charles [...] mourut aussi à Barcelonne, non sans grande opinion d'avoir esté empoisonné par les pratiques de D[ona] Jeanne, sa marastre [...] Il fut fort regretté de tous les Catalans, qui l'apelloyent leur soleil levant [...] On faisoit courir ce bruit, que l'ame du prince Dom Charles se plaignoit de nuict par les rues de Barcelonne, demandant vengeance de la royne D[ona] Jeanne, qui l'avoit contrainte par poison de se séparer de son corps, ayant quelque temps devant avorté la royne d'une frayeur qui la saisit, s'en venant à Gironne, d'un estrange feu qui l'alluma en ses cheveux par un seul rayon du soleil qui luy donna sur la teste. Chose notable comme éstant un advertissement du ciel contre les injustes procédures de ceste dame en l'Estat de Navarre \& d'Aragon. La cause fuit jugée par les naturalistes, les lavemens \& poudres desquelles elle se servoit pour colorer ou descolorer sa chevelure naturelle ${ }^{25}$.

El mismo Olhagaray reincide en la culpabilidad de Juana Enríquez al relatar su muerte, retomando y alterando levemente la expresión que ya habían formulado los Col.loquis en boca de la moribunda reina, estando con su hijo: "Dit-on qu'elle eust ces dernières paroles à la bouche parlant à Ferdinand: -O mon fils, que tu me coustes cher-, of les originaux sont chargez de ce qu'elle confessa avoir esté cause de la mort de D [om] Charles» ${ }^{26}$. Pocos años después, André Favyn reiteraba en su Histoire de Navarre (París, 1612) una narración de los hechos no muy diferente a la de Olhagaray, aunque sí más extensa y efectista. Se aprecian significativos cambios en la actuación de la reina moribunda pronunciando sus últimas palabras, pues ahora Juana Enríquez no interpela a Fernando sino al mismo don Carlos, a quien se dirige con el apelativo de hijo: la madrastra está sumergida en un delirio que la hace sońar y ver continuamente la imagen recriminatoria del príncipe de Viana. Sin omitir las apariciones del príncipe implorando venganza por las calles de Barcelona, la obra de Favyn especifica que la reina consiguió el veneno a través del médico de don Carlos y que, a los tres días de haber maquinado el homicidio, sufrió en su cuerpo las consecuencias de un cáncer. Lo que más salta a la vista es el patetismo de la escena:

La mort du prince Charles n'advança pas les affaires du roy Jean d'Aragon, contre lequel les Cattelans, ceux du Comté de Roussillon, d'Ampurdan \& autres conduicts par le comte de Paillars, se révoltèrent en un moment pour vanger la mort de leur prince Charles, l'âme duquel revenoit se promenant toutes les nuicts par les rues de Barcelonne, se plaignant d'avoir esté empoisonné traistreusement par sa marastre, contre laquelle il imploroit la vengeance divine.

[...]

Mais voyons la catastrophe de la royne d'Aragon D[ona] Jeanne Henríquez, seconde femme de Jean d'Aragon, meurtrier du prince Charles de Navarre, son beaufils. Trois jours après qu'elle eut arresté avec son médecin d'empoisonner le prince, afin que son fils Dom Ferdinand heritast seul de tous les royaumes \& seigneuries dudict Jean d'Aragon, elle se sentit frappée d'un cancer à la mammelle gauche qui luy

25. Pierre Olhagaray, Histoire de Foix, Bearn et Navarre, diligemment recveillie, tant des precedens historiens que des Archives desdites maison, París, s/n, 1609, p. 367. La confusión entre las dos Juanas es advertida por Nuria Coll Juliá, op. cit., 1, p. 17.

26. Pierre Olhagaray, op. cit., p. 372. Nótese que en La perla de Cataluña de Gregorio de Argaiz ya hemos encontrado la referencia que Olhagaray hace a fuentes originales donde se confirma que la reina confesó su culpabilidad. Vid. el texto al que remite la nota 19. 
rongea les parties nobles, huict ans durant \& jusques en l'an mil quatre cents soixante \&neuf, qu'après avoir souffert des tourments indicibles elle se veid mourir toute vive, n'ayant eu depuis cest empoisonnement que des songes estranges \& visions effroyables qui la bourelloient jour \& nuict sans relasche; ce qui faisoit à tous moments eslancer des cris lamentables: $-O$ mon fils, que tu me bourrelles \& tourmentes?-, ayant tousjours devant les yeux l'image du prince de Navarre la talonnant pas à pas \& l'adjournant à comparoistre devant la justice divine ${ }^{27}$.

Aunque otras autoridades francesas reiteran algunos de los elementos que hasta ahora hemos comentado, apenas se detienen en este asunto y no aportan nada nuevo en relación a lo que Pierre Olhagaray y André Favyn hicieron constar por escrito. Podemos decir, pues, que la leyenda del envenenamiento de don Carlos alcanza un grado de desarrollo considerable gracias a la reelaboración de la cual fue objeto en diversas obras historiográficas del siglo XVII o anteriores. El papel de la antagonista, Juana Enríquez, la supuesta maquinadora del crimen, va ganando con el tiempo una importancia cada vez mayor, aunque no faltan detalles de otros personajes implicados en la trama como el rey Juan II o el primogénito Fernando. Algunas veces entra en juego un médico o un brevaje supuestamente curativo que, en realidad, resulta ser venenoso. El espectro de don Carlos revela el secreto apareciéndose de noche por las calles de Barcelona e implorando venganza. Podríamos decir que esta narración tiene todas las características de una reelaboración literaria, pero las noticias escritas poco después de la muerte del príncipe no nos permiten dudar de su repercusión histórica, de modo que lo que ahora consideramos una leyenda se tenía entonces por caso verdadero y notorio.

\section{TRES VERSIONES DE UN CRIMEN, DOCUMENTADAS ENTRE I 46 I Y I 464}

Después de este breve panorama por diversas obras historiográficas, nos centraremos ahora en tres pasajes que fueron escritos poco después de la muerte de don Carlos y que, entre las fuentes manuscritas coetáneas, destacan por ser los que más explícitamente se refieren al presunto envenenamiento. El primer caso sucedió cuando todavía no se había cumplido un trimestre desde la muerte de don Carlos, mientras que los otros dos coinciden en su cronología con los inicios de la guerra civil, justo cuando la figura del príncipe de Viana fue más explotada por la propaganda política y militar de Cataluña ${ }^{28}$. No deja de ser curioso que cada uno de los tres testimonios reconstruya una versión diferente del crimen, sin que eso signifique que se contradigan entre ellos.

27. André Favyn, Histoire de Navarre, contenant l'origine, les vies \& conquestes de ses roys, depuis leur commencement iusques a present, París, Laurent Somnius / Pierre Mettayer / Pierre Chevallier, 1612, p. 584 y 587. El caso del envenenamiento de don Carlos maquinado por la reina y el castigo que esta recibe es tratado por extenso en las p. 583-584 y 587-588 de la obra de Favyn.

28. Sobre la importancia simbólica y propagandística del príncipe de Viana durante la guerra

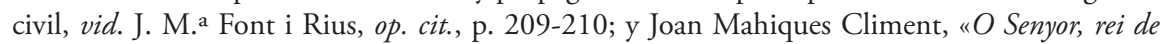
Glòria / Senyor, rei de Glòria: difusió i significat de l'Oratio beati Karoli», Estudis Romànics, no 36, 2014, en prensa. 
El primer ejemplo lo encontramos casi con las mismas palabras en dos dietarios diferentes pero ambos redactados por Jaume Safont. Nos referimos, por una parte, al Dietari o Llibre de Jornades y, por otra parte, al Dietari de la casa de la Diputació i General de Catalunya de aquel período: una nota del día 18 de diciembre de 1461 pregona la muerte del especiero Antoni Jaume después de haber ingerido exactamente las mismas píldoras que él mismo había administrado al príncipe de Viana durante la prisión del castillo de Morella, es decir, entre el 14 y el 25 de febrero de $1461^{29}$. Una mano censora intentó borrar este fragmento del manuscrito del Dietari de la casa de la Diputació $i$ General de Catalunya, expurgo que imposibilita la lectura íntegra del pasaje ${ }^{30}$. Por eso lo citaremos a partir del Llibre de Jornades:

Spacier. Divenres, a XVIII de deembre MCCCCLXI, a III hores de matí, passà d'esta vida n'Anthoni Jacme, spacier de sent Karles, primogènit d'Aragó, de sancta recordació, lo qual féu lo tast de certes pindoles que li foren dades stant ell pres en lo castell de Morella. E mori de semblant mal que lo dit sanct mori; lo qual spacier fonch ubert ab licència e permissió de la senyora reyna, e foren-li trobades totes les frexures pudrides, axi punt per punt com eren stades trobades aquelles del beneÿt sent Karles la hora que.l ubriren, aprés sa beneventurada mort. Loat sia Déu de tot! ${ }^{31}$

$\mathrm{Al}$ morir don Carlos, se le abrió su cuerpo para enbalsamarlo y encontraron los pulmones totalmente podridos, como también sucedió en la autopsia de Antoni Jaume ${ }^{32}$. Esta semejanza y el hecho que ambos tomasen los mismos medicamentos hicieron suponer que Antoni Jaume era realmente el autor del homicidio de don Carlos. Por tanto, se trataría de un veneno lento que, después de ser ingerido, acabaría haciendo su efecto al cabo de medio año. Por inverosímil que parezca dicha suposición, los rumores que relacionaban la muerte del príncipe con la enfermedad de Morella todavía eran esgrimidos

29. El mismo 25 de febrero de 1461 fue aceptada la liberación de don Carlos por parte de Juan II, que estaba en Zaragoza. Esta noticia llegó a Morella al día siguiente, tal como indica Georges Desdevises du Dézert, op. cit., p. 361-371.

30. Cf. Josep Maria Sans i Travé (dir.), Dietaris de la Generalitat de Catalunya. Volum I. Anys 1411 a 1539. Director de l'obra: Josep Maria Sans i Travé, Director de l'Arxiu Nacional de Catalunya. A cura de: Lluïsa Cases i Loscos, Josep Fernàndez i Trabal, Laureà Pagarolas i Sabaté, Barcelona, Generalitat de Catalunya, 1994, p. 170-171.

31. Jaume Safont, Dietari o Llibre de Jornades (1411-1484) de Jaume Safont. A cura de Josep Maria Sans i Travé, Barcelona, Fundació Noguera, 1992, p. 145. Pasaje comentado por Luis Cutchet y Víctor Balaguer, Cataluña vindicada. La ciudadela de Barcelona. Obra histórica escrita por D. Luis Cutchet y D. Victor Balaguer, ilustrada por Lechard y por Martinez, Barcelona, Imprenta Nueva de Jaime Depús y Ramon Villegas, 1858, p. 338; Antonio de Bofarull y Brocá, Historia crítica (civil y eclesiástica) de Cataluña. Tomo VI: Condes, reyes de Aragón (línea femenina de Castilla), Barcelona, Juan Aleu y Fugarull, 1877, p. 76-77; y Manuel Iribarren, op. cit., p. 204.

32. Vid. Georges Desdevises du Dézert, op. cit., p. 411; y José-Luis Martín Rodríguez, op. cit., p. 53-55. Los comentarios de Desdevises du Dézert y de Martín Rodríguez toman como fuente documental a Pere Joan Comes, Libre de algvnes coses asanyalades succehides en Barcelona y altres parts, format per Pere Joan Comes en 1583 y recóndit en lo Arxiu del Excelentissim Ajuntament, ara per primera volta publicat ab deguda llicencia baix la revisió de D. Joseph Puiggari, Barcelona, La Renaixensa, 1878, p. 178. 
en pleno Romanticismo como argumentos que hacían suponer una intriga escabrosa con posible homicidio. Así lo creían, por ejemplo, Luis Cutchet y Víctor Balaguer, que para sostener su hipótesis citaban un documento de la época que advertía cómo "lo dit senyor Primogenit apres fonch dins lo castell se destempra de mal de passio colica e stava molt flach e ferenhi muntar un metge de la dita vila» ${ }^{33}$.

Las otras dos versiones fueron escritas en los inicios de la guerra civil de Cataluña (1462-1472), aunque cada una de ellas fue redactada desde lugares y puntos de vista muy distintos. La primera es debida a Hug Roger III, conde de Pallars y comandante del ejército de la Diputación del General de Cataluña que luchó en Girona contra las huestes favorables a Juan II. La segunda fue escrita desde la Sede Apostólica por el papa Pío II, que antes de su pontificado era conocido como el cardenal Enea Silvio Piccolomini, importante humanista y escritor italiano. El día 15 de junio de 1462, desde Girona, Hug Roger III envió una carta a los diputados explicándoles cómo había arrestado a maese Vesach, imputado por el presunto envenenamiento del príncipe de Viana:

Pler trop singular en la presa de mestre Vesach, de què mian sus ara avisat. Certament deu portar la pena que mareix, e si bé serà stret e deu-se fer en tot cas, sabreu moltes coses damnatissimes, e singularment lo fet de les metzines del sant primogènit, de què ell és stat principal factor. Plàcia-us fer-hi la diligència que.s puga, que aqueix scelerat d'home ha cabut en moltes coses e sap en tots los actes que.s són fets fins a la hora e tenguts ${ }^{34}$.

De este maese Vesach, que acabaría burlando a sus guardianes y escapándose por el valle de Andorra, se ha conjeturado un origen gascón, y ha sido identificado con Joan de Vesach, médico que trabajó para Juan II y que bajo las instrucciones de Juana Enríquez realizó diversas gestiones políticas en los

33. Próspero de Bofarull y Mascaró, Colección de documentos inéditos del archivo general de la Corona de Aragón. Tomo XV [Levantamiento y guerra de Cataluña en tiempo de don Juan II. Documentos relativos á aquellos sucesos. Tomo II], Barcelona, Imprenta del Archivo, 1858, p. 137. A partir de ahora citaremos la Colección de documentos inéditos del archivo general de la Corona de Aragón utilizando el acrónimo CODOINACA, más el número del volumen en cifras arábigas. Este documento ya fue citado por Luis Cutchet / Víctor Balaguer, op. cit., p. 291. Reproducimos a continuación la opinión de Georges Desdevises du Dézert: «Es difícil admitir que un veneno administrado antes del 10 de marzo deje a la víctima en pie durante seis meses y no la mate hasta el 23 de septiembre. El príncipe, que era de carácter suspicaz, y que sólo estaba rodeado en los últimos meses de su vida por enemigos de la reina, no tuvo ni por un instante la idea de morir envenenado. Todos los síntomas de su enfermedad presentan un carácter muy natural. Su cuerpo se conservó mucho tiempo intacto, después de su muerte, y la autopsia no reveló ningún hecho extraordinario", Georges Desdevises du Dézert, op. cit., p. 409.

34. Jaume Sobrequés i Callicó y Ramon Sarobe i Huesca, Hug Roger III. Epistolari de guerra $i$ exili del darrer comte de Pallars (1451-1500). Presentació: Ferran Rella, Barcelona, Editorial Base, 2008, p. 147. Pasaje también editado por Manuel de Bofarull y de Sartorio, CODOINACA, 20 [Levantamiento y guerra de Cataluña en tiempo de don Juan II. Documentos relativos á aquellos sucesos. Tomo VII], Barcelona, Imprenta del Archivo, 1861, p. 333; y comentado por J. M. ${ }^{\text {a Font }}$ i Rius, op. cit., p. 208. 
albores de la guerra civil ${ }^{35}$. Si fuese cierta la hipótesis de su origen gascón, las sospechas que acusaban a este médico podrían haberse visto propiciadas por las manifestaciones de intolerancia popular-no exentas de motivaciones políticasque los catalanes mostraban contra los gascones: recordemos que Juan II tenía en Gastón IV de Foix, esposo de su hija Leonor, un aliado gascón a quien ofreció en herencia el principado de Viana y el reino de Navarra, quebrantando los derechos hereditarios de don Carlos y de su hermana Blanca. Durante los inicios de la guerra civil de Cataluńa, las guarniciones de Gastón IV lucharon tanto en Girona como en el condado de Pallars, dos frentes en los que Hug Roger III estaba directamente involucrado: si en Girona era comandante del ejército que luchaba contra el rey, en el condado de Pallars era propietario y señor ${ }^{36}$. A la luz de estos datos, podemos decir que pudo pesar no solamente la intolerancia general del vulgo sino también las circunstancias concretas del cerco de Girona y las reacciones de Hug Roger III ante las continuas ofensivas de los gascones. La situación del conde de Pallars ha sido notada por Jaume Sobrequés:

\footnotetext{
A primers de juny de 1462 té notícies que «en lo comdat e terres mies se preparen los gascons de entrar». [...]

El 30 de juny el comte manifesta, des de Girona, que «mos vassalls [...] stan en gran perill e congoxes" per causa de l'amenaça gascona, "que, si presta provisió no si fa, stà aquell mon comdat en punt de perdrés. E no stich sens molta congoxa, que stant yo en servey del Principat faça tal pèrdua, que no solament ne va dan, mas encara, a la honor, mancament».

Quan, a primers d'agost de 1462, els exèrcits gascons comencen a entrar al Pallars, Hug Roger que, un cop abandonat el setge de Girona, es troba a Hostalric es desespera davant de la indiferència del Consell del Principat ${ }^{37}$.
}

35. Vid. Luis Cutchet y Víctor Balaguer, op. cit., p. 338-339; Antonio de Bofarull y Brocá, op. cit., p. 77-79; Manuel Iribarren, op. cit., p. 205-206; Nuria Coll Juliá, op. cit., 1, p. 3941, 212 y 333-334; A. Rovira i Virgili, Història nacional de Catalunya. Volum VII, Barcelona, Edicions Pàtria, 1934, p. 451-452; CODOINACA, 20, p. 262-263 y 341-343; y Manuel de Bofarull y de Sartorio, CODOINACA, 21 [Guerra de Cataluña en tiempo de Juan II. Documentos relativos á aquellos sucesos. Tomo VIII], Barcelona, Imprenta del Archivo, 1861, p. 211-213.

36. Vid. Santiago Sobrequés i Vidal y Jaume Sobrequés i Callicó, La guerra civil catalana del segle XV. Estudis sobre la crisi social i econòmica de la Baixa Edat Mitjana. Volum primer: causes $i$ desenvolupament de la crisi, Barcelona, Edicions 62, 1973, p. 158 y 351-352. Pero poco antes de la guerra, el día 27 de marzo de 1461, se pregonó por toda la ciudad de Barcelona «que d'ecí per demà tot die, tot gaschó e castellà qui no haja muller o no tenga casa pròpria o llogada en Barcelona hic haja exir, sots pena de mort», Josep Maria Sans i Travé (dir.), op. cit., p. 161; cf. Jaume Safont, op. cit., p. 133. Este caso estaría regido por una legislación de excepción adoptada en momentos de conflicto político-militar, según indica M. Mercè Gras i Casanovas, «La immigració francesa i la legislació. Els nouvinguts i els poders de la terra», en El poder real en la Corona de Aragón (Siglos XIV-XVI) [XV Congreso de Historia de la Corona de Aragón. Actas: Tomo I], Zaragoza, Gobierno de Aragón, 1996, p. 123-134 (especialmente la p. 128).

37. Jaume Sobrequés i Callicó, «El llenguatge nacional d'Hug Roger III, comte de Pallars (1461-1463)», en Hug Roger III, darrer comte de Pallars. De la glòria a l'ocàs, Tremp, Garsineu Edicions, 2003, p. 35-50 (p. 40-41). Vid. también Jaume Sobrequés i Callicó y Ramon Sarobe i Huesca, op. cit., p. 158, 167, 195-196 y 198-199. 
La acusación y el arresto de maese Vesach tiene muchos puntos en común con la primera de las tres versiones que estamos analizando, donde el acusado no era médico sino especiero. Claro está que se trata de dos profesiones claramente emparentadas, que implicaban no solo un buen conocimiento de las sustancias curativas o venenosas sino también un fácil acceso a estas mismas. Diversas obras historiográficas también mencionan explícitamente o dan por supuesta la intervención de un profesional de la medicina en el presunto envenenamiento: pensemos en el brebaje de los Col-loquis de Despuig, o en el médico del que habla Favyn.

Por otra parte, Pío II murió en el 14 de agosto de 1464, antes de que acabase la guerra civil de Cataluña, a la cual se refiere en sus Comentarii rerum memorabilium. El papa adoptaba en esta obra un punto de vista muy personal, cosa que no contradice que fuese uno de los testigos coetáneos menos parciales que escribieron sobre estos asuntos ${ }^{38}$. Pío II manifiesta sin rodeos la risa y el menosprecio que le inspiraba la exagerada relación de los milagros de don Carlos, a quien los catalanes querían canonizar, y no dejaba de denunciar su fama póstuma como una manipulación política encubierta bajo capa de devoción. Pero lo que más nos interesa es la frase en la que Pío II menciona la existencia de rumores que aseguraban, literalmente, que el príncipe fue asesinado con el veneno paterno: "Carolum paterno veneno interfectum» ${ }^{39}$.

Los Comentarii se limitan a constatar lo que divulgaban y creían los catalanes, sin confirmar ni negar su veracidad. Lo poco que nos dicen sobre el presunto homicidio nos hace suponer que la noticia, tal como llegó a Roma, ponía más énfasis en la culpabilidad del padre que en el papel que se le atribuía a la madrastra o a otros implicados en el supuesto crimen. ¿Pero quién informó al papa, y de qué modo? No hemos encontrado ninguna alusión al homicidio en las misivas que los representantes de la Diputación o del cabildo de Barcelona dirigieron a los miembros de la Curia Pontificia, o viceversa. Los documentos de las embajadas enviadas desde Barcelona ponían énfasis en los milagros del príncipe y en la conveniencia de que se abriese el proceso de su canonización, pero nada decían sobre el supuesto homicidio: podemos pensar que no habría sido procedente notificarlo por escrito, pero tampoco descartamos que los mismos embajadores comentasen oralmente lo que no osarían escribir ${ }^{40}$.

38. Vid. J. M. Pons i Guri, «Catalunya en els comentaris d'Enea Silvio Piccolomini», Annals de l'Institut d'Estudis Gironins, no 29, 1987, p. 161-178.

39. Pío II (Enea Silvio Piccolomini), Pii Secundi Pontificis Max. Commentarii Rerum memorabilium, quae temporibus suis contigerunt, à $R$. D. Ioanne Gobellino vicario Bonnen. iamdiu compositi, \& à R. P. D. Francisco Band. Picolomineo Archiepiscopo Senensi ex vestusto originali recogniti. Et Sanctiss. D. N. Gregorio XIII. Pont. Max. dicati, Romae, ex Typographica Dominici Basae, 1584, p. 314.

40. Sobre las embajadas que la Diputación y el Consejo del Principado envió a Roma, vid. Josep M. Pou i Martí, «Relacions del papa Pius II amb Joan II d'Aragó i els catalans», Analecta Sacra Tarraconensia. Anuari de la Biblioteca Balmes [Homenatge a Antoni Rubió i Lluch], no 12, 1936, p. 359-382 (especialmente las p. 369-370); J. M. ${ }^{a}$ Font i Rius, op. cit., p. 213-217; y los comentarios y documentos publicados por Manuel de Bofarull y de Sartorio, CODOINACA, 18 [Levantamiento y guerra de Cataluña en tiempos de don Juan II. Documentos relativos a aquellos 
A pesar de sus divergencias, las tres versiones que acabamos de estudiar constituyen una prueba irrefutable de la historicidad de los rumores y sospechas de envenenamiento, que acusaban explícitamente no a la madrastra sino a otros personajes, ya fuese un especiero, un médico o el padre de la víctima. Claro está que la omisión de Juana Enríquez no nos permite negarle el papel de instigadora en cada una de las tres tramas, que solo podemos reconstruir en parte, ya que nos encontramos ante testimonios extremadamente concisos, que relatan los hechos de manera fragmentaria y desde una perspectiva sesgada o externa.

\section{4. "SCRIPTURA NO POT EXPLICAR»: RUMORES, TEXTOS Y CONTEXTOS, DEL 26 DE SEPTIEMBRE AL 2 I DE NOVIEMBRE DE I 46I}

Acabamos de ver cómo el papa Pío II había oído hablar del supuesto envenenamiento de don Carlos, aunque en la correspondencia que llegó a Roma desde Barcelona no hemos encontrado ninguna alusión a estos rumores. Este ejemplo nos puede ayudar a entender hasta qué punto influyen los canales de difusión a la hora de deducir el impacto de un suceso determinado, aunque dicha constatación resultaría todavía más evidente tras el análisis de algunos documentos dirigidos sobre todo a Juan II, entonces establecido en Calatayud, los cuales se referían a opiniones del vulgo de Barcelona sobre la conducta de la reina.

Del día 26 de septiembre es una carta que Manuel de Montsuar y los demás diputados y representantes del Consejo dirigían a los embajadores que enviaron ante el rey, en la cual constataban el estado de conmoción y tristeza que había trastornado la quietud de Barcelona y de sus alrededores tras el fallecimiento de don Carlos, cuyo cuerpo obraba milagrosas curaciones con solo tocarlo. Este testimonio también nos permite intuir el papel del cabildo y del cuerpo de notarios y escribanos de Barcelona, que difundieron la fama de santidad y los milagros no solamente mediante las voces que corrían y la predicación sino también mediante la emisión y autentificación de escrituras. Aunque los diputados explicaban todas estas cosas y otras semejantes con gran profusión de detalles, se expresaron de manera más enigmática en el siguiente pasaje:

Aquestes coses [...] qui son mes e en major conturbacio que scriptura no pot explicar, necessariament nos han fets entrar en molts pensaments, zelants sempre fidelissimament lo servey de la majestat, del senyor Rey, conservacio de la sua reyal posteritat e lo repos de aquest Principat: d'on, considerant lo passat e lo present, e hoides moltes populars opinions qui.s prediquen de la mort del dit senyor Primogenit, e altres coses que exprimir no curam, som recayguts en comuna deliberacio [...] investigueu si la majestat del senyor Rey deliberara la serenissima senyora Reyna vingue ab lo illustrissimo senyor don Ferrando, Primogenit; e si axi sabieu esser veridicament, en tal cas, per gran servici dels dits senyor Rey, Reyna e illustrissimo

sucesos. Tomo V], Barcelona, Imprenta del Archivo, 1860, p. 82 y 103-112, 333-335, 441-445 y $478-482$. 
Primogenit e repos del dit Principat, suplicareu humilment e devota, de part de aquest Principat, la excellencia del dit senyor Rey [...] vulle ordonar e dispondre lo dit illustrissimo don Ferrando vingue sens la dita senyora Reyna ${ }^{41}$.

La Diputación y el Consejo encomendaban a sus embajadores que averiguasen si Juan II tenía la intención de que la reina acompañase a Fernando a Barcelona y, si se daba esta eventualidad, que por el bien común suplicasen al rey que el nuevo primogénito se presentase en esta ciudad sin su madre. Lo más curioso es que la recomendada ausencia de Juana Enríquez tenía una relación directa con las populares opiniones que corrían por la capital del Principado, las cuales -según dice el texto citado- no se podían explicar por escrito. Se trata, sin duda, del mismo asunto turbio que sugieren otras misivas de fechas muy próximas, como sucede en una de los diputados para sus embajadores escrita el 30 de septiembre, que apenas se atreve a insinuar la proliferación de "vulgars oppinions predicades de la mort del dit Illustre don Karlos» y "moltes oppinions en aquest Principat per les quals utilment aplanar e assossegar es vist e necessari [...] seguirse ab affecte les coses supplicades", insistiendo además que, si el rey sigue las instrucciones propuestas por la Diputación y el Consejo, "sera grandissimo repos e assossech en los animos dels cathalans e lunyara totalment totes oppinions e pensaments» ${ }^{42}$.

Más explícita es una carta del 11 de octubre de 1461, en la que los diputados advirtieron a sus embajadores cómo "en lo vulgo es edificada e per continua demostracio dels miracles qui nunca cessen ratificada opinio que la mort del Illustre don Karlos de sancta recordacio fill primogenit del dit Senyor Rey no naturalment ses seguida per la qual raho se dien moltes paraules» ${ }^{43}$. Con el argumento de la extensión de esta sospecha popular -la muerte violenta de don Carlos-, los diputados daban instrucciones a sus embajadores para convencer al rey de que Juana Enríquez se abstuviese de entrar en Barcelona. Los diputados aseguraban que, si Fernando llegaba a la ciudad sin su madre, todos estos chismes acabarían desvaneciéndose con el tiempo ${ }^{44}$. Casi con las mismas palabras, esta misma idea es reiterada poco después en una respuesta del 16 de octubre donde los embajadores confirman la recepción de la correspondencia enviada por los diputados:

Venint apres ab la dita letra al fet de la anada de la Illustrissima Senyora Reyna e commemorant lo sentiment donat per lo Senyor Rey segons vos havem scrit de voler attendre a la disposicio e a les coses que concorrien e fer lo que la diposicio de aquell importaria e li consellaria veniu a narrar la oppinio en lo vulgo edificada e per continua demostracio dels miracles que nuncha cessen radicada. Ço es que la mort

41. Nuria Coll Juliá, op. cit., 2, p. 242. La misma estudiosa comenta este fragmento en el vol. 1, p. 109-110.

42. CODOINACA, 18, p. 73.

43. Ibid., p. 128.

44. «Certificants vos mossenyors nostra ferma creença esser que les dites e altres vulgars oppinions e pensaments intrinsechs e extrinsechs pendra perfeta curacio venint al present lo dit Illustre Primogenit sens la dita Senyora Reyna lo qual com dit havem ab molta devocio e amor es sperat", Ibid. 
del Illustrissimo don Carles de sancta recordacio fill primogenit del dit Senyor Rey no naturalment serie seguida de que se dien moltes paraules. Per tant volen e disponen per nosaltres circa lo dit article esser continuades les supplicacions acostumades ab narracio de les causes dessus dites les quals vos impellexen les dites supplicacions fer per nostre descarrech ${ }^{45}$.

A pesar de los rodeos y la indeterminación con que estos documentos aluden a la difusión de vulgares opiniones, sí que se nos dice claramente que estas se referían a la muerte no natural de don Carlos y que la alteración general que habían provocado en Barcelona recomendaba que la reina demorase su entrada en dicha ciudad. Sin pecar de excesiva audacia, podemos concluir que los diputados y embajadores se referían a las sospechas de que Juana Enríquez había urdido el envenenamiento del príncipe de Viana.

En todo caso, el lunes 26 de octubre de 1461, el rey y los embajadores escribieron a los diputados advirtiéndoles que la voluntad de Juan II era que don Fernando fuese acompañado de Juana Enríquez hacia Barcelona, donde ejercería como primogénito y lugarteniente de Cataluña bajo la tutela materna. El monarca se excusó arguyendo que su hijo se había disgustado sobremanera al enterarse de que no le acompañaría su madre. La partida fue fijada para el jueves 29 de octubre. Los embajadores, que fueron retenidos por el rey, todavía tenían muy presentes las vulgares opiniones que se extendían por Barcelona:

\footnotetext{
Secundariament lo dit Senyor Rey nos ha dit e explicat com la sua Altesa delliberava trametre en aqueix Principat lo Illustre Primogenit lo qual dijous primer vinent al tot mes larch partiria sens alguna fallença e per tant lo dit Senyor Rey pregava e encarregava nosaltres aturassem fins en aquella jornada per anar nos ne en companya del dit Illustre Senyor Primogenit ço que era digna cosa e pertinent de la devocio e bona amor de aqueix Principat e succehiria en tranquillitat repos $e$ benefici de aquell com si altrament nosaltres partissem ab tot que per gracia de Deu la voluntat amor e gracia de sa Excellencia envers lo dit Principat e la devocio fidelitat e amor de aquell envers sa Excellencia son bonissimes e quals entre Senyor e bons vassalls esser deuen. Pero no restaria que en lo vulgo no insurtis algun parlament crehent que per la tal nostra partida on no haguesem lo dit Illustre Primogenit sperat fos alguna ruptura de que se causarien en los animos recels e sinistres opinions que per lo repos del dit Principat deuen esser repellides e squivades ${ }^{46}$.
}

En el fondo, y por encima de las razones aparentes que esgrimían tanto los poderes civiles de Cataluńa como la autoridad real, lo que se estaba gestando era una nueva pugna entre dos fuerzas políticas opuestas. Detrás de los rumores que inculpaban a Juana Enríquez de un supuesto homicido también se escondía una posible estrategia de los diputados para demorar la influencia directa de la reina en el gobierno de Cataluña. Desde la capitulación del 21 de junio de 1461 en Vilafranca del Penedès, Juan II había perdido la potestad de entrar libremente en el Principado sin el permiso previo de la Diputación. La eventual llegada de la reina a Barcelona y su intervención como tutora del

45. Ibid., p. 154-155.

46. Ibid., p. 198-199. En las p. 194-204 de este volumen se editan la carta del rey y la de los embajadores, ambas con la fecha de 26 de octubre de 1461. 
verdadero lugarteniente que era Fernando podía hacer peligrar la integridad de las libertades que el gobierno civil de Cataluña había conseguido tras el pacto de Vilafranca:

la alarmada reacción del rey ante la enérgica actitud de los diputados consistió no sólo en desvanecer todo presunto recelo de demora indefinida, fijando para ello la fecha de la marcha de su hijo, sino también en dilucidar, de manera definitiva, el problema de si la reina iría al Principado. Es preciso considerar los motivos por los cuales los diputados concedian una importancia tan capital a esta ida. Su explicación de que los rumores sobre el envenenamiento del príncipe de Viana se desvanecian si don Fernando partiera solo es sumamente sencilla, pero cuesta admitir que sea igualmente simple. Sin duda la capitulación de Villafranca no habia logrado extinguir la impopularidad que habia valido a doña Juana el proceso de don Carlos; pero es dificil desechar la sospecha de que en aquella tenaz oposición no se ocultara, además, el deseo de impedir la proyección, a través de persona tan adicta a Juan II, de la autoridad del Rey en el Principado ${ }^{47}$.

La reina y su hijo llegaron a Barcelona el 13 de noviembre casi sin haber avisado y sin haber concertado previamente ninguna ceremonia de recepción, razón por la cual se pospuso dicha celebración para el día 21. Tenemos poderosos motivos para concluir que esta inesperada visita disgustó a los diputados, tal como Jaume Safont da a entender tanto en el Dietari de la casa de la Diputació $i$ General de Catalunya como en el Llibre de Jornades. El pasaje en cuestión remite al mismo día 21, y nos habla de dos extrańas señales acaecidas en la catedral de Barcelona: la primera cuenta cómo la cuerda de una de las campanas mayores se rompió hasta cinco veces, de manera reiterada e inmediata, incluso después de ser repuesta. La segunda explica cómo, estando la reina y su hijo, se desmoronó un pilar de mármol del altar mayor que estaba más cerca del palacio real, que es donde murió el príncipe de Viana. Detrás de estos portentos parece esconderse un correlato simbólico del difunto primogénito de Aragón, puntal y fundamento de las libertades catalanas, caído bajo la influencia nefasta de Juana Enríquez, que habría actuado con premeditación y alevosía. Así es cómo la figura de la madrastra queda envuelta de una aura de signos funestos y claramente recriminatorios. Después de todo lo dicho, no debe extrañarnos que, en el manuscrito de cada uno de los dietarios, este pasaje haya sido expurgado con una tachadura que, de todos modos, no impide la lectura del texto:

e fas aci memòria com, volent los capellans sonar los senys majors, la corda de un dels dits senys se trenchà, e corrent tornaren-la afegir, e encara no l'agueren afegida ella.s tornà trencar, e axi fonch trencada e afegida $V$ vagades aquell deprés dinar, segons la relació dels preveres de la Seu. E, entrada la dita senyora reyna e lo dit senyor primogènit en la Seu, muntaren fer oració al altar major, e seguís un altra

47. Nuria Coll Juliá, op. cit., 1, p. 112-113. El motivo de la entrada de la reina en Barcelona y su trasfondo político es estudiado en las p. 105-140 del volumen que acabamos de citar. Sobre las consecuencias de la capitulación de Vilafranca del Penedès en las relaciones políticas que se establecerían entre Juan II y el Principado de Cataluña, vid. la síntesis de J. N. Hillgarth, La hegemonía castellana (1410-1474). Los reinos hispánicos, 2, Barcelona / Buenos Aires / México, Grijalbo, 1983, p. 304-305. 
gran seny(al), car la hun pilar de marbre d'aquells dos qui stan devant l'altar major, cayg(ué) e.s troçajà en moltes pesses, ço és, aquell pilar qui és pus prop del palau reyal ${ }^{48}$.

Los ejemplos que acabamos de abordar tienen el interés de establecer una relación directa entre los rumores de envenenamiento y el intento de posponer la entrada de la reina en Barcelona. Se trata de un detalle de suma importancia que pasaría desapercibido en la tradición historiográfica posterior, y que nos permite intuir que las sospechas de homicidio no eran una mera murmuración espontáneamente difundida por el pueblo, sino que, dentro del marco de los enfrentamientos entre los poderes reales y civiles, era objeto de una manipulación propagandística y política. Por otra parte, si excluimos las milagrosas apariciones de don Carlos por los aires animando a los solados que luchaban por Cataluña, salta a la vista la ausencia de testimonios de la época de Juan II que representen al espectro del príncipe reclamando venganza, tal como hemos encontrado en Lucio Marineo o Cristòfor Despuig ${ }^{49}$.

\section{Conclusiones}

A través de diversas fuentes documentales del Archivo de la Corona de Aragón publicadas sobre todo por Manuel de Bofarull, se pueden reconstruir muchos de los medios de difusión que los diputados y el Consejo utilizaron para pregonar, desde Barcelona y más allá de los límites de la Corona, la santidad y los milagros del bienaventurado don Carlos. Pero si el príncipe fue considerado como un santo, no es menos cierto que también fue visto en su época como una víctima desdichada. Corrió la voz de un presunto envenenamiento que muchos atribuían a las instigaciones de la madrastra Juana Enríquez, aunque otros también acusaban a su padre Juan II, al especiero Antoni Jaume o a maese Vesach. Las pocas noticias escritas durante los días o meses sucesivos a la muerte del príncipe de Viana nos aseguran que entonces ya comenzaron a propagarse estas sospechas. Mucho más tardías son las primeras manifestaciones que describen al espectro del difunto vagando por las calles de Barcelona y reclamando venganza, ya que el más antiguo de los casos lo hemos localizado en la crónica De rebus Hispaniae memorabilibus de Lucio Marineo, publicada en el año 1533.

Hemos abordado nuestro tema de estudio a partir de fuentes de diversa índole y de épocas distantes, que van desde el año 1461 hasta el final del siglo

48. Josep Maria Sans i Travé (dir.), op. cit., p. 170; cf. Jaume Safont, op. cit., p. 143-144. Los respectivos editores de los dos dietarios constatan la expurgación de este pasaje.

49. En efecto, este tipo de apariciones de difuntos debe distinguirse de las milagrosas epifanías de santos, ángeles u otros seres bienaventurados que animan a los soldados en la batalla, como sucede en la típica representación de Santiago o san Jorge. En nuestro estudio hemos excluído este último tipo de apariciones, aunque algunas misivas firmadas por el conde Hug Roger III de Pallars afirmaban que el glorioso príncipe de Viana había sido visto por los aires durante la batalla de Girona, tal como indica J. M. ${ }^{a}$ Font i Rius, op. cit., p. 209-210; y Manuel Iribarren, op. cit., p. 240. 
XVII. Por una parte, las cartas que escribieron los diputados y sus embajadores nunca se refieren explícitamente a las sospechas de envenenamiento, aunque parece incuestionable que aluden a ello de manera velada cuando señalan la existencia de gravísimas opiniones del vulgo de Barcelona como pretexto para que Juana Enríquez retardase su entrada en esta ciudad. Debemos advertir que algunos de los acusados por el veredicto popular -el rey y la reina- podrían ser destinatarios de tales misivas o estar implicados en las negociaciones diplomáticas que justificaban la redacción de las mismas. Sea como sea, el uso de estas murmuraciones como pretexto para limitar el ámbito de actuación de la reina es de suma importancia para determinar el origen de los rumores y su trasfondo ideológico, político y propagandístico.

La tradición historiográfica tiene la ventaja de ser mucho más explícita al relatar los hechos, hasta el punto de señalar claramente lo que a penas se insinúa en la documentación de la época de Juan II. A pesar de su diversa índole y de su cronología divergente, la confrontación entre las fuentes historiográficas y las archivísticas nos ha permitido notar algunas conexiones, como sucede en la triple acusación de la madrastra, el padre y el médico, aunque el rasgo que más destaca entre la diversidad de fuentes es la tradición oral: siempre se nos habla de murmuraciones, opiniones o manipulaciones masivas. El énfasis que se pone en un aspecto o en otro depende de la afinidad política de quienes lo escriben: Lucio Marineo, partidario de Fernando el Católico y, por tanto, también de Juan II, carga las tintas contra la rebelión de Cataluña y contra la fama póstuma de don Carlos, mientras que Cristòfor Despuig combina la defensa del príncipe y las libertades catalanas con el vituperio de la madrastra Juana Enríquez. También hemos insistido en la gran cantidad de detalles que Despuig aporta sobre los orígenes y la transmisión oral de esta leyenda hasta el primer tercio del siglo XVI, así como en su evolución hasta el final del siglo XVII, aunque la presencia del desdichado príncipe atraviesa toda la edad moderna hasta llegar a la actualidad, pasando por la etapa del Romanticismo, y todavía pervive en algunas leyendas catalanas locales que nos recuerdan cómo un médico judío preparó un brebaje de efecto retardado a instancias de la madrastra, y cómo después de muerto el mismo don Carlos se vengó de su padre ${ }^{50}$.

50. Vid. Bienve Moya, Llegendes del Penedès i les valls del Garraf, Barcelona, Publicacions de l'Abadia de Montserrat, 2005, p. 85-87; Josep Campmany, Manel Alonso, Montserrat Campmany, Alícia Estrada, Xavier Garcia, Néstor Gómez, Germán Ráfales y Benet Solina, Gavà, Valls, Cossetània, 2001, p. 132; Manuel Iribarren, op. cit., p. 205; y Joan Amades, Les cent millors llegendes populars, Barcelona, Editorial Selecta, 1953, p. 185-190. 


\section{Bibliografía}

Abarca Pedro, Segunda parte de los anales historicos de los reyes de Aragon por el p. maestro Pedro Abarca, Salamanca, Lucas Pérez, 1684.

Amades Joan, Les cent millors llegendes populars, Barcelona, Editorial Selecta, 1953.

Argaiz Gregorio de, La perla de Cataluña. Historia de Nvestra Señora de Monserrate, Madrid, Imprenta de Andrés García de la Iglesia, 1677.

Baranda Nieves, «Una crónica desconocida de Juan II de Aragón (Valencia, 1541)», Dicenda. Cuadernos de Filología Hispánica, 1987, no 7, p. 267-288.

[Belloy Pierre de], Declaration dv droit de legitime svccession sur le royavme de Portugal, apartenant à la Royne mere du Roy Treschrestien [...] Par M. P. BE. IV. TH., Anvers, s/n, 1582 .

Bofarull y Brocá Antonio de, Historia critica (civily eclesiástica) de Cataluña. VI: Condes, reyes de Aragón (línea femenina de Castilla), Barcelona, Juan Aleu y Fugarull, 1877.

Bofarull y de Sartorio Manuel de, Colección de documentos inéditos del archivo general de la Corona de Aragón. 18, Levantamiento y guerra de Cataluña en tiempos de don Juan II. Documentos relativos a aquellos sucesos. Tomo V, Barcelona, Imprenta del Archivo, 1860.

Bofarull y de Sartorio Manuel de, Colección de documentos inéditos del archivo general de la Corona de Aragón. 20, Levantamiento y guerra de Cataluña en tiempo de don Juan II. Documentos relativos á aquellos sucesos. Tomo VII, Barcelona, Imprenta del Archivo, 1861.

Bofarull y de Sartorio Manuel de, Colección de documentos inéditos del archivo general de la Corona de Aragón. 21, Guerra de Cataluña en tiempo de Juan II. Documentos relativos á aquellos sucesos. Tomo VIII, Barcelona, Imprenta del Archivo, 1861.

Bofarull y Mascaró Próspero de, Colección de documentos inéditos del archivo general de la Corona de Aragón. 15, Levantamiento y guerra de Cataluña en tiempo de don Juan II. Documentos relativos á aquellos sucesos. Tomo II, Barcelona, Imprenta del Archivo, 1858.

Campmany Josep, Alonso Manel, Campmany Montserrat, Estrada Alícia, Garcia Xavier, Gómez Néstor, Ráfales Germán y Solina Benet, Gavà, Valls, Cossetània, 2001.

[Chappuys Gabriel], L'histoire dv Royavme de Navarre, contenant de Roy en Roy tout ce qui y est aduenu de remarquable des son origine, París, Nicolas Gilles, 1596.

Closas Antoni, El primogènit Carles, Princep de Viana, Barcelona, Rafael Dalmau, 1977.

Coll Juliá Nuria, Doña Juana Enríquez, lugarteniente real en Cataluña (1461-1468), Madrid, Consejo Superior de Investigaciones Científicas, 1953, 2 vol.

Comes Pere Joan, Libre de algvnes coses asanyalades succehides en Barcelona y altres parts, format per Pere Joan Comes en 1583 y recóndit en lo Arxiu del Excelentíssim Ajuntament, ara per primera volta publicat ab deguda llicencia baix la revisió de D. Joseph Puiggari, Barcelona, La Renaixensa, 1878.

Cruells Manuel, El princep Carles de Viana, Barcelona, Barcino, 1935.

Cutchet Luis y Balaguer Víctor, Cataluña vindicada. La ciudadela de Barcelona. Obra histórica escrita por D. Luis Cutchet y D. Victor Balaguer, ilustrada por Lechard y por Martinez, Barcelona, Imprenta Nueva de Jaime Depús y Ramon Villegas, 1858. 
Desdevises du Dézert Georges, Don Carlos de Aragón, príncipe de Viana. Estudio sobre la España del norte en el siglo XV. Edición y traducción: Pascual Tamburri Bariain, Pamplona, Gobierno de Navarra, 1999.

Despuig Cristòfor, Los col-loquis de la insigne ciutat de Tortosa. Edició crítica d'Enric Querol i Josep Solervicens, Barcelona, Publicacions de l'Abadia de Montserrat, 2011.

Dubler César E., La «Materia Médica» de Dioscórides. Transmisión medievaly renacentista. 3, La «Materia Médica» de Dioscórides traducida y comentada por D. Andrés de Laguna (texto crítico), Barcelona, Tipografía Emporium, 1955.

Duran Eulàlia, «La funció de les llegendes en la historiografia», Estudi General, 20032004, no 23-24, p. 63-79.

Duran Eulàlia (dir.), Repertori de manuscrits catalans (1474-1620). Volum IV. Direcció: Eulàlia Duran. Compilació a cura de: Maria Toldrà (coordinació), Mar Batlle, Carme Camps, Antoni Cobos, Joan Mahiques, Eulàlia Miralles, Enric Querol, Joan Requesens, Glòria Sabaté, Barcelona, Institut d'Estudis Catalans, 2008.

Faraudo de Saint-Germain Luis (ed.), El "Libre de les medicines particulars». Versión catalana trescentista del texto árabe del tratado de los medicamentos simples de Ibn Wáfid, autor médico toledano del siglo XI. Transcripción, estudio proemial y glosarios por Luis Faraudo de Saint-Germain, Barcelona, Real Academia de Buenas Letras de Barcelona, 1943.

Favyn André, Histoire de Navarre, contenant l'origine, les vies \& conquestes de ses roys, depuis leur commencement iusques a present, París, Laurent Somnius / Pierre Mettayer / Pierre Chevallier, 1612.

Font i Rius J. M. ${ }^{a}$, «La tradició de la santedat del príncep de Viana», La Paraula Cristiana, 1934, no 117, p. 196-223.

Font i Rius J. M.a ${ }^{a}$ «El príncep de Viana a la Seu de Barcelona. Algunes notes sobre la veneració popular de Carles de Viana", Analecta Sacra Tarraconensia. Anuari de la Biblioteca Balmes [Homenatge a Antoni Rubió i Lluch], 1936, nº 12, p. 541-557.

Garibay y Çamalloa Esteban de, Compendio historial de las chronicas y vniversal historia de todos los reynos d'España, donde se ponen en summa los condes, señores de Aragon, con los Reyes d'el mesmo reyno: y condes de Barcelona, y reyes de Napoles y Sicilia, Anveres, Christophoro Plantino, 1571.

Gómez Redondo Fernando, Historia de la prosa medieval castellana. 4, El reinado de Enrique IV: el final de la Edad Media. Conclusiones. Guía de lectura. Apéndices. Índices, Madrid, Cátedra, 2007.

Gras i Casanovas M. Mercè, "La immigració francesa i la legislació. Els nouvinguts i els poders de la terra", en El poder real en la Corona de Aragón (Siglos XIV-XVI) [XV Congreso de Historia de la Corona de Aragón. Actas: Tomo I], Zaragoza, Gobierno de Aragón, 1996, p. 123-134.

Hillgarth J. N., La hegemonia castellana (1410-1474). Los reinos hispánicos, 2, Barcelona / Buenos Aires / México, Grijalbo, 1983.

Iribarren Manuel, El principe de Viana (un destino frustrado), Barcelona, Montaner y Simón, 1947.

Mahiques Climent Joan, "O Senyor, rei de Glòria / Senyor, rei de Glòria: difusió i significat de l'Oratio beati Karoli», Estudis Romànics, no 36, 2014, en prensa. 
Mahiques Climent Joan, "Les ànimes d'ultratomba: una justificació propagandistica», Estudi General, 2003-2004, no 23-24, p. 143-160.

Marineo Sículo Lucio, L. Marinei Sicvli regii historiographi opus de rebus Hispaniae memorabilibus modo castigatum atq. Caesareae maiestatis iussu in lucem aeditum, Alcalá de Henares, Michaelem de Eguia, 1533.

Martín Rodríguez José Luis, «Biografía y leyenda del Príncipe de Viana -sant Carles de Viana-», en Benito Ruano Eloy (coord.), Tópicos y realidades de la Edad Media (III), Madrid, Real Academia de la Historia, 2004, p. 27-67.

Moya Bienve, Llegendes del Penedès i les valls del Garraf, Barcelona, Publicacions de l'Abadia de Montserrat, 2005.

Olhagaray Pierre, Histoire de Foix, Bearn et Navarre, diligemment recveillie, tant des precedens historiens que des Archives desdites maison, París, s/n, 1609.

Palencia Alfonso de, Gesta Hispaniensia ex annalibvs svorvm diervm collecta. 2, Libri VI-X. Edición, estudio y notas de Brian Tate y Jeremy Lawrance, Madrid, Real Academia de la Historia, 1999.

Paz y Meliá A., El cronista Alonso de Palencia: su vida y sus obras; sus "Décadas» y las "Crónicas» contemporáneas; ilustraciones de las «Décadas» y notas varias, Madrid, Hispanic Society of America (Tipografía de la Revista de Archivos), 1914.

Pío II (Enea Silvio Piccolomini), Pii Secundi Pontificis Max. Commentarii Rerum memorabilium, quae temporibus suis contigerunt, à $R$. D. Ioanne Gobellino vicario Bonnen. iamdiu compositi, \& à R. P. D. Francisco Band. Picolomineo Archiepiscopo Senensi ex vestusto originali recogniti. Et Sanctiss. D. N. Gregorio XIII. Pont. Max. dicati, Roma, Typographica Dominici Basae, 1584.

Pons i Guri J. Ma., "Catalunya en els comentaris d'Enea Silvio Piccolomini», Annals de l'Institut d'Estudis Gironins, 1987, no 29, p. 161-178.

Pou i Martí Josep M., «Relacions del papa Pius II amb Joan II d'Aragó i els catalans», Analecta Sacra Tarraconensia. Anuari de la Biblioteca Balmes [Homenatge a Antoni Rubió i Lluch], 1936, no 12, p. 359-382.

Querol Coll Enric, "Cristòfol Despuig, pugna pro patria. Noves dades biogràfiques sobre l'autor dels Col-loquis», Llengua \& Literatura, 2005, no 16, p. 247-288.

Ramírez Vaquero Eloísa y Tamburri Bariain Pascual, El príncipe de Viana, Pamplona, Gobierno de Navarra, 2001.

Rovira i Virgili A., Història nacional de Catalunya. Volum VII, Barcelona, Edicions Pàtria, 1934.

Safont Jaume, Dietari o Llibre de Jornades (1411-1484) de Jaume Safont. A cura de Josep Maria Sans i Travé, Barcelona, Fundació Noguera, 1992.

Sánchez-Parra María Pilar, Crónica anónima de Enrique IV de Castilla, 1454-1474. (Crónica castellana). Edición crítica y comentada de María Pilar Sánchez-Parra, Madrid, Ediciones de la Torre, 1991, 2 vol.

Sans i Travé Josep Maria (dir.), Dietaris de la Generalitat de Catalunya. Volum I. Anys 1411 a 1539. Director de l'obra: Josep Maria Sans i Travé, Director de l'Arxiu Nacional de Catalunya. A cura de: Lluïsa Cases i Loscos, Josep Fernàndez i Trabal, Laureà Pagarolas i Sabaté, Barcelona, Generalitat de Catalunya, 1994. 
Sobrequés i Callicó Jaume, «El llenguatge nacional d'Hug Roger III, comte de Pallars (1461-1463)», en Hug Roger III, darrer comte de Pallars. De la glòria a l'ocàs, Tremp, Garsineu Edicions, 2003, p. 35-50.

Sobrequés i Callicó Jaume y Sarobe i Huesca Ramon, Hug Roger III. Epistolari de guerra $i$ exili del darrer comte de Pallars (1451-1500). Presentació: Ferran Rella, Barcelona, Editorial Base, 2008.

Sobrequés i Vidal Santiago y Sobrequés i Callicó Jaume, La guerra civil catalana del segle $X V$. Estudis sobre la crisi social i econòmica de la Baixa Edat Mitjana. Volum primer: causes i desenvolupament de la crisi, Barcelona, Edicions 62, 1973.

Solervicens Josep, Els Pä̈sos Catalans i Espanya: ser o no ser. Conflictes político-lingüistics al segle XVI, Valencia, Tres i Quatre, 1988.

Solervicens Josep, El diàleg renaixentista: Joan Lluis Vives, Cristòfor Despuig, Lluis Milà, Antoni Agustí, Barcelona, Publicacions de l'Abadia de Montserrat, 1997.

Toda Eduard, «La tragèdia final del príncep de Viana», en Discursos llegits en la Real Academia de Buenas Letras de Barcelona en la solemne recepció pública del iltre. Sr. D. Eduard Toda el dia 2 de desembre de 1930, Barcelona, Imp. "La Renaixensa», 1930, p. 1-27.

Torres Fontes Juan, Estudio sobre la "Crónica de Enrique IV» del Dr. Galíndez de Carvajal, Murcia, Consejo Superior de Investigaciones Científicas / Instituto Jerónimo de Zurita / Seminario de Historia de la Universidad de Murcia, 1946.

Valera Diego de, Memorial de diversas hazañas. Crónica de Enrique IV, ordenada por mosén Diego de Valera. Edición y estudio de Juan de Mata Carriazo, Madrid, EspasaCalpe, 1941.

Vicens i Vives Jaume, «Trayectoria mediterránea del príncipe de Viana (1458-1461)», en Obra dispersa. A cura de M. Batllori i E. Giralt. Catalunya ahir i avui. Pròleg de Ramon d'Abadal i de Vinyals, Barcelona, Editorial Vicens-Vives, 1967, p. 83-108.

Vivanco Laura, Death in fifteenth-century Castile: ideologies of the elites, Woodbridge, Tamesis, 2004. 